\title{
Comparisons of Curative Effects of Chlorophyll from Sauropus androgynus (L) Merr Leaf Extract and Cu-Chlorophyllin on Sodium Nitrate-Induced Oxidative Stress in Rats
}

\author{
Suparmi Suparmi, ${ }^{1}$ Minidian Fasitasari, ${ }^{2,3}$ Martanto Martosupono, ${ }^{4}$ \\ and Jubhar Christian Mangimbulude ${ }^{4}$ \\ ${ }^{1}$ Department of Biology, Faculty of Medicine, Universitas Islam Sultan Agung, Semarang 50112, Indonesia \\ ${ }^{2}$ Department of Clinical Nutrition, Faculty of Medicine, Universitas Islam Sultan Agung, Semarang 50112, Indonesia \\ ${ }^{3}$ Sultan Agung Islamic Hospital, Semarang 50112, Indonesia \\ ${ }^{4}$ Master Program of Biology, Satya Wacana Christian University, Jl. Diponegoro 52-60, Salatiga 50711, Indonesia
}

Correspondence should be addressed to Suparmi Suparmi; suparmi@unissula.ac.id

Received 3 August 2016; Accepted 24 October 2016

Academic Editor: Orish Ebere Orisakwe

Copyright (C) 2016 Suparmi Suparmi et al. This is an open access article distributed under the Creative Commons Attribution License, which permits unrestricted use, distribution, and reproduction in any medium, provided the original work is properly cited.

Sodium nitrate $\left(\mathrm{NaNO}_{2}\right)$ widely used as food additive for coloring and preserving meat has been reported to induce oxidative stress and cause histopathologic changes, nitrosative tissue damage, and lipid peroxidation in liver and kidney. Therefore, the present study compared the curative effect of chlorophyll from Sauropus androgynus (L) Merr and $\mathrm{Cu}$-chlorophyllin as antioxidant in $\mathrm{NaNO}_{2}$ induced female Wistar rats based on haematological, serum biochemical, and histological evaluation. Thirty male Wistar rats were randomly assigned into six groups of five rats each. $\mathrm{NaNO}_{2}$ were given at a subacute dose of $50 \mathrm{mg} / \mathrm{kg}$ bw intraperitoneally for 10 days. Chlorophyll from S. androgynus and $\mathrm{Cu}$-chlorophyllin from $\mathrm{K}$-Liquid ${ }^{\mathrm{TM}}$ were given in the following 14 days at the two doses: $0,016 \mathrm{mg} / \mathrm{mL}$ and $0.008 \mathrm{mg} / \mathrm{mL}$. $\mathrm{NaNO}_{2}$ exposure resulted in significant reductions $(p<0.05)$ in values of packed cell volume (PCV), haemoglobin $(\mathrm{Hb})$ concentration and red blood cell (RBC) count, transferrin, and ferritin and elevation in malondialdehyde (MDA) level and schistocytes percentage with insignificant reductions in serum albumin and transferrin levels. Histology of kidney and liver were changed insignificantly $(p>0.05)$ to normal values. Chlorophyll from S. androgynus and Cu-chlorophyllin possess antioxidant potentials to protect against toxicities induced by sodium nitrate.

\section{Introduction}

Sodium nitrate $\left(\mathrm{NaNO}_{2}\right)$ is one of important environmental toxicants and poses important health risks. Most countries use $\mathrm{NaNO}_{2}$ as food additive as a source of color and flavor preservation in meat products and this chemical can also be found in water resources [1]. Consumption of $\mathrm{NaNO}_{2}$ at low levels for long time caused histopathologic changes, nitrosative tissue damage, and lipid peroxidation in liver and kidney, as well as inducing chromosomal aberrations [2], decreased immune system [3], increased cancer colon risk [1], hypoxia, enlargement of the carotid body, and a vasodilation due to the activity with haemoglobin in the blood to form methaemoglobin, which has a much higher (up to 20 times) affinity for oxygen $[4,5]$. Acute intraperitoneal treatment of Wistar rats with $\mathrm{NaNO}_{2}$ (at the dose of $50 \mathrm{mg} / \mathrm{kg} \mathrm{bw}$ ) influences the blood rheological properties and erythrocyte hematometric indices. As very little data are available on the effort to cure the intoxication of $\mathrm{NaNO}_{2}$, the aim of this work was to evaluate the curative effect of chlorophyll from Sauropus androgynus (L) Merr as antioxidant to cure its toxic effect in inducing oxidative stress.

Dietary chlorophyll can be found in fresh fruits and vegetables as chlorophyll $a$ and chlorophyll $b$, thermally 
processed fruits and vegetables as metal-free pheophytins and pyropheophytins, and thermally processed green vegetables as $\mathrm{Zn}$-pheophytins and Zn-pyropheophytins [6]. Chlorophyll in form of underutilized greens in fresh vegetables, supplements, liquid solutions, extracts, or tablets can be used effectively as healthy and beneficial nutrient supplement [7]. Antioxidant activity is one of the beneficial effects of chlorophylls to prevent oxidative DNA damage and lipid peroxidation both by reducing reactive oxygen species (ROS) and chelating metal ions [8-11]. Chlorophylls can act as a hydrogen donor to break the chain reaction, due to the porphyrin in its chemical structure [12].

Sauropus androgynus (L) Merr was identified as potentially rich sources of chlorophyll $[13,14]$. The antioxidant activities of the dark green leaves of $S$. androgynous were reported to have biologically nutritive value. Among others, they have antidiabetic activity in diabetic mice induced by alloxan [15], reduce fever, increase breastmilk production, and prevent hoarse voice [16]; have antidyslipidemic activity and prevent the cardiovascular disorder in Wistar male rats induced with fat-rich diet [17]; affect the growth performances, resist diseases, and enhance nonspecific immune responses in grouper diets [18]. The previous study reported that antioxidant activity of chlorophyll from S. androgynous leaves is able to decrease schistocytes percentage and malondialdehyde (MDA) level and also increase the level of haemoglobin $(\mathrm{Hb})$ and ferritin in female mice induced by $\mathrm{NaNO}_{2}$ [19]. This work may provide new information for toxicological testing to validate the safety and traditional uses of these plants.

$\mathrm{Cu}$-chlorophyllin reported has a higher antioxidant activity than that of natural chlorophylls due to the presence of the chelated metal in the porphyrin ring. The antioxidant activities of the $\mathrm{Cu}$-chelated compounds were found to be much higher than those of natural chlorophylls and of $\mathrm{Mg}$ free derivatives [11]. This study also compared the curative effect of natural chlorophyll in S. androgynus leaves compared to $\mathrm{Cu}$-chlorophyllin antioxidant activity in female rats induced subacute sodium nitrite $\left(\mathrm{NaNO}_{2}\right)$. Haematological blood assays and the level of MDA, ferritin, and transferrin in blood serum were analysed as curative effect indicator of chlorophyll, while the histopathologic view of liver and kidney tissues was used to evaluate its toxicity.

\section{Material and Methods}

2.1. Chemicals. All chemicals were of analytical grade. Fresh leaves of S. androgynus (L) Merr were collected from the inhabitant park in Penggaron Lor Village, Genuk, Semarang, Central Java, Indonesia. Cu-chlorophyllin from K-Liquid was obtained from a drug store in Semarang, Central Java, Indonesia.

2.2. Extract Preparation of Chlorophyll from S. androgynus Leaves. A given amount ( $200 \mathrm{~g})$ of fresh leaves was cleaned and was thereafter blended with acetone : methanol $(7: 3, \mathrm{v} / \mathrm{v})$ using an electric blender until the pigment was removed. Ascorbic acid was added to the solution to avoid degradation of the pigment. The extract was filtered to remove insoluble material. The filtrate obtained was then partitioned with diethyl ether three times sequentially. The organic phase material that resulted was added steadily with $\mathrm{Na}_{2} \mathrm{SO}_{4}$ anhydrate to ensure no water in the extract. The solvent removal and drying process of chlorophyll used rotary evaporator and $\mathrm{N}_{2}$ gas. The yield of the extraction process was harvested and kept at $4^{\circ} \mathrm{C}$ for use. A suspension of $0.016 \mathrm{mg}$ of chlorophyll from S. androgynus (L) Merr leaf extract (CSA) was dissolved in $1 \mathrm{~mL}$ distilled water, used as a dose 1 of CSA, while for making $1 / 2$ dose CSA $0.008 \mathrm{mg} / \mathrm{mL}$ was diluted from 1 dose CSA.

2.3. Experimental Animals. Thirty female Wistar albino rats (150-200 g) were obtained from the Faculty of Pharmacy, Universitas Gadjah Mada, Yogyakarta, Indonesia. Rats were maintained in the animal house of Faculty of Medicine, Universitas Islam Sultan Agung in standard hard bottom polypropylene cages at $23^{\circ} \mathrm{C} \pm 2^{\circ} \mathrm{C}, 12: 12 \mathrm{~h}$ light/dark cycle and free access to laboratory chow and tap water throughout the study. Ethical clearance was obtained from the Ethics Committee of the Faculty of Medicine, Universitas Islam Sultan Agung, Indonesia, with document number 150/V/2015/Komisi Bioetika.

The animals were randomly divided into six groups, comprising five rats per group. All groups were acclimatized for 7 days prior to treatment. $\mathrm{NaNO}_{2}$ was administered $50 \mathrm{mg} / \mathrm{kg}$ body weight (dissolved in $1 \mathrm{~mL}$ distilled water), which refers to rate of $\mathrm{LD}_{50}$ on rats [20]. $\mathrm{NaNO}_{2}$ as much as $1 \mathrm{~mL} /$ day was given intraperitoneally to the rats for 10 days for treated animals (groups II, III, IV, V, and VI). The control rats (group I) were treated with the same volume of distilled water. During the following 14 days, the rats from groups III and IV were given orally dose $1 / 2(0.008 \mathrm{mg} / \mathrm{mL})$ and dose $1(0.016 \mathrm{mg} / \mathrm{mL})$ of CSA, respectively, whereas the rats from groups $\mathrm{V}$ and $\mathrm{VI}$ were given $\mathrm{Cu}$-chlorophyllin from K-Liquid with dose $1 / 2(0.008 \mathrm{mg} / \mathrm{mL})$ and dose 1 $(0.016 \mathrm{mg} / \mathrm{mL})$, respectively. Cu-chlorophyllin was dissolved in distilled water based on the instruction in the packing. The solution of chlorophyll and $\mathrm{Cu}$-chlorophyllin, those given to rat, were $3 \mathrm{~mL} /$ head/day according to the conversion of adult man doses.

2.4. Blood Sampling. Blood samples were collected from the animals via the periorbital sinus $24 \mathrm{~h}$ after the last treatment. About $3 \mathrm{~mL}$ of the blood was allowed to clot at room temperature. The clotted blood samples were centrifuged at $3000 \mathrm{rpm}$ for $10 \mathrm{~min}$ to obtain the serum, which was used for biochemical analyses. Another $2 \mathrm{~mL}$ of the blood samples was collected into heparinized tubes that were used for haematological assays.

2.5. Haematological Blood Assays. The packed cell volume (PCV) was estimated by the microhematocrit method and the $\mathrm{Hb}$ concentration by the cyanmethemoglobin. Red blood cell (RBC) counts were determined using the new improved Neubauer hemocytometer. Schistocytes are detected in the peripheral blood smear stained using wedge procedures and observed by microscopy in 100x every 1000 erythrocytes. 
TABLE 1: The hematological parameters in each experimental group.

\begin{tabular}{lcccccc}
\hline Parameters & $\begin{array}{c}\text { Group I } \\
\text { control }\end{array}$ & $\begin{array}{c}\text { Group II } \\
\left(\mathrm{NaNO}_{2}\right)\end{array}$ & $\begin{array}{c}\text { Group III } \\
\left(\mathrm{NaNO}_{2}+\text { dose } 1 / 2\right.\end{array}$ & $\begin{array}{c}\text { Group IV } \\
\left(\mathrm{NaNO}_{2}+\text { dose } 1\right. \\
\text { CSA })\end{array}$ & $\begin{array}{c}\text { Group V } \\
\left(\mathrm{NaNO}_{2}+\mathrm{dose}^{1 / 2}\right.\end{array}$ & $\begin{array}{c}\text { Group VI } \\
\left(\mathrm{NaNO}_{2}+\mathrm{dose}^{2}\right)\end{array}$ \\
\hline $\mathrm{PVC}(\%)$ & $38.00 \pm 2.05$ & $36.80 \pm 0.86$ & $33.20 \pm 0.80^{\mathrm{a}}$ & $35.20 \pm 1.93$ & $38.25 \pm 0.75$ & $40.80 \pm 1.85$ \\
$\mathrm{Hb}(\mathrm{g} / \mathrm{dL})$ & $13.74 \pm 1.18^{\mathrm{b}}$ & $9.26 \pm 0.71^{\mathrm{a}}$ & $10.50 \pm 0.84^{\mathrm{a}}$ & $15.32 \pm 1.57^{\mathrm{b}}$ & $13.52 \pm 1.03^{\mathrm{b}}$ & $12.84 \pm 0.33^{\mathrm{b}}$ \\
$\mathrm{RBC}\left(\times 10^{6} / \mathrm{mm}^{3}\right)$ & $565.20 \pm 14.95^{\mathrm{b}}$ & $677.60 \pm 33.62^{\mathrm{a}}$ & $526.40 \pm 49.55^{\mathrm{b}}$ & $571.80 \pm 41.49$ & $633 \pm 40.32$ & $606.60 \pm 32.83$ \\
Fragmentocyte $(\%)$ & $0.02 \pm 0.02^{\mathrm{b}}$ & $0.20 \pm 0.03^{\mathrm{a}}$ & $0.10 \pm 0.03$ & $0.02 \pm 0.02^{\mathrm{b}}$ & $0.12 \pm 0.06$ & $0.16 \pm 0.06^{\mathrm{a}}$ \\
\hline
\end{tabular}

Note: values are presented as mean \pm SE of five animals per group. ${ }^{a}$ Value differs significantly from control; ${ }^{b}$ value differs significantly compared to $\mathrm{NaNO}_{2}$ alone. $\mathrm{NaNO}_{2}$ : sodium nitrate; PCV: packed cell volume; RBC: red blood cell; $\mathrm{Hb}$ : haemoglobin.

2.6. Biochemical Evaluation. Commercially available kits were used according to the respective manufacturer's protocol for the measurement of MDA, ferritin, and transferrin. MDA level was measured using Thio Barbituric Acid Reactive Substance (TBARS) test with $532 \mathrm{~nm}$ wavelength spectrophotometer, whilst ferritin level was measured using Enzyme Linked Immunosorbent Assay (ELISA) method. The measurement of transferrin level was using automatic analyser.

2.7. Histological Study. All the animals were then sacrificed by anesthetizing with diethyl ether $24 \mathrm{~h}$ after the last treatment. The liver and kidney samples were collected in $10 \%$ formalin for histopathological analysis. The organ tissues were processed and embedded in paraffin wax and sections were made of about 4-6 $\mu \mathrm{m}$. After staining with haematoxylin and eosin, slides were examined under the microscope (Olympus, Japan) for histopathological changes and photographed. The histopathologic parameters for liver were scored as follows: (1) showing no changes or normal, (2) parenchymatous degeneration, (3) hydropic degeneration, and (4) necrosis, while the scoring for proximal tubule epithelium was as follows: (1) lesion less than $25 \%$ indicating no change, (2) lesion $25 \%-<50 \%$, (3) lesion $50 \%-<75 \%$, and (4) lesion more than $75 \%$ showing severe changes [21].

2.8. Statistical Analyses. Results are reported as mean values \pm SEM and statistically analysed by One-Way ANOVA test with $95 \%$ significance level. If the data characteristics did not allow for the One-Way ANOVA test to be conducted, then the Kruskal-Wallis test became the alternative. A post hoc test was conducted where needed.

\section{Results and Discussion}

3.1. Haematological Evaluation. Values of haematological parameters are presented in Table 1 . The $\mathrm{Hb}$ in induced $\mathrm{NaNO}_{2}$ rats group was significantly lower $(p<0.05)$ than that of rats in control groups. It indicated that the subacute administration of $\mathrm{NaNO}_{2}$ can cause anaemia which was indicated by the decrease of $\mathrm{Hb}$ level, PCV percentage, increase the RBC concentration, and schistocytes percentage. Changes in blood parameters and immune response are the direct toxic effects due to high dose administration of $\mathrm{NaNO}_{2}$
[22]. Hb level and PVC are considered to be most appropriate indicators of anaemia. PVC indicates the proportion of whole blood occupied by the $\mathrm{RBC}$ and depends on the $\mathrm{Hb}$ level in RBC. The percentages of schistocytes in $\mathrm{NaNO}_{2}$-induced rats group were significantly higher than control group which proved that $\mathrm{NaNO}_{2}$ is able to damage the resulting fragmented RBCs called as schistocytes. The schistocytes may have different forms such as triangular, helmet, or comma shaped of broken or fragmented erythrocytes [23]. $\mathrm{NaNO}_{2}$ affects the haematological and hemorheological parameters in mature rats $[5,24]$.

The group that was treated with one-dose chlorophyll from $S$. androgynous showed significant difference in $\mathrm{Hb}$ level, RBC concentration when compared with the $\mathrm{NaNO}_{2}$ group $(p<0.05)$, but no significant difference with the $\mathrm{Cu}-$ chlorophyllin in the same dose and control group. This indicated that the natural chlorophyll from $S$. androgynous leave is as effective as $\mathrm{Cu}$-chlorophyllin to cure the oxidative stress caused by $\mathrm{NaNO}_{2}$ induction. The haematological parameters as $\mathrm{PCV}, \mathrm{Hb}$, and schistocytes in in the lower dose group of $S$. androgynous chlorophyll and $\mathrm{Cu}$-chlorophyllin were not significantly different $(p>0.05)$ compared to those in the $\mathrm{NaNO}_{2}$ group, which indicated that lower dose of chlorophyll was not more effective at ameliorating the anaemia symptoms induced by $\mathrm{NaNO}_{2}$.

$\mathrm{NaNO}_{2}$ is one of methaemoglobin-forming drugs that may exacerbate oxidative toxicity under certain chronic or acute hemolytic settings. $\mathrm{NaNO}_{2}$ that will react with $\mathrm{Hb}$ may enhance heme- or iron-mediated toxicities [25]. The increasing of $\mathrm{Hb}$ level showed that $\mathrm{NaNO}_{2}$ induced erythrocyte methemoglobinemia by increasing reactive oxygen species (ROS) [26]. The fusion of the heme moiety of hemoglobin released from red blood cells into endothelium could provide catalytically active iron to the vasculature. Ferritin as a cytoprotection against free radicals in vitro will be increased in the increasing of ROS [27].

3.2. Serum Biochemistry. Table 2 presents serum biochemical parameters from six groups. The MDA level increased significantly in $\mathrm{NaNO}_{2}$ induction group, whereas transferrin and ferritin level were reduced significantly with exposure to $\mathrm{NaNO}_{2}$ when compared with control. Treatment with chlorophyll and $\mathrm{Cu}$-chlorophyllin restored the values of these parameters. 
TABLE 2: The serum biochemical parameters in each experimental group.

\begin{tabular}{|c|c|c|c|c|c|c|}
\hline Parameters & $\begin{array}{l}\text { Group I } \\
\text { control }\end{array}$ & $\begin{array}{l}\text { Group II } \\
\left(\mathrm{NaNO}_{2}\right)\end{array}$ & $\begin{array}{c}\text { Group III } \\
\left(\mathrm{NaNO}_{2}+\text { dose } 1 / 2\right. \\
\text { CSA })\end{array}$ & $\begin{array}{c}\text { Group IV } \\
\left(\mathrm{NaNO}_{2}+\text { dose } 1\right. \\
\text { CSA })\end{array}$ & $\begin{array}{c}\text { Group } \mathrm{V} \\
\left(\mathrm{NaNO}_{2}+\text { dose } 1 / 2\right. \\
\mathrm{CuC})\end{array}$ & $\begin{array}{c}\text { Group VI } \\
\left(\mathrm{NaNO}_{2}+\text { dose } 1\right. \\
\mathrm{CuC})\end{array}$ \\
\hline $\mathrm{MDA}(\mathrm{nmol} / \mathrm{mL})$ & $1.26 \pm 0.05^{\mathrm{b}}$ & $4.55 \pm 0.13^{\mathrm{a}}$ & $2.88 \pm 0.11^{\mathrm{a}, \mathrm{b}}$ & $2.13 \pm 0.10^{\mathrm{a}, \mathrm{b}}$ & $3.35 \pm 0.09^{\mathrm{a}, \mathrm{b}}$ & $2.53 \pm 0.05^{\mathrm{a}, \mathrm{b}}$ \\
\hline Transferrin (\%) & $27.21 \pm 0.18^{\mathrm{b}}$ & $19.36 \pm 0.42^{\mathrm{a}}$ & $24.32 \pm 0.06^{\mathrm{a}, \mathrm{b}}$ & $26.14 \pm 0.03^{\mathrm{b}}$ & $22.64 \pm 0.84^{\mathrm{a}, \mathrm{b}}$ & $25.48 \pm 0.49^{\mathrm{a}, \mathrm{b}}$ \\
\hline Ferritin $(\mu \mathrm{g} / \mathrm{L})$ & $113.80 \pm 1.18^{\mathrm{b}}$ & $58.20 \pm 2.08^{\mathrm{a}}$ & $75.80 \pm 2.06^{\mathrm{a} . \mathrm{b}}$ & $93.80 \pm 1.77^{\mathrm{a}, \mathrm{b}}$ & $65.25 \pm 1.75^{\mathrm{a}, \mathrm{b}}$ & $86.60 \pm 1.91^{\mathrm{a}, \mathrm{b}}$ \\
\hline
\end{tabular}

Note: values are presented as mean $\pm \mathrm{SE}$ of five animals per group. ${ }^{\mathrm{a}}$ Value differs significantly from control; ${ }^{\mathrm{b}}$ value differs significantly compared to $\mathrm{NaNO}_{2}$ alone. MDA: malondialdehyde.

ROS are important mediators of cellular degeneration. In the body, nitrate is reduced to nitrite [1] and nitrite is converted to nitrosonium ions which in turn reacts with amines and amides to form nitrosamines and nitrosamines, respectively [28]. N-nitrosamines have the ability to induce rapid oxidative stress [29] and then cause lipid peroxidation; therefore it disturbs the cellular homoeostasis [30].

The serum MDA level is one of the molecules used as indicator of lipid peroxidation to estimate oxidative stress [29]. Present study showed that rats who received $\mathrm{NaNO}_{2}$ for 10 days showed increasing of the MDA serum significantly compared to control group. This result is in accordance with the previous studies that elevated MDA level in $\mathrm{NaNO}_{2}$-given mice [31] and elevated levels of serum MDA in rats given $\mathrm{NaNO}_{2}$ [32]. Results from this study revealed that treatment with chlorophyll of $S$. androgynus restored MDA levels after $\mathrm{NaNO}_{2}$ treatments to normal values. The MDA level in group II which was not treated by the chlorophyll remained high (see Table 2). The decreasing of MDA levels in group III till group VI after the $\mathrm{NaNO}_{2}$ treatments is the results of the antioxidant activity of chlorophyll of $S$. androgynus and $\mathrm{Cu}$-chlorophyllin. The same effects were observed for serum ferritin and transferrin. Decreased serum transferrin and ferritin levels could be a result of damage, particularly protein oxidation by reactive oxygen species generated by $\mathrm{NaNO}_{2}$ toxicity. There was a decrease $(p<0.05)$ in serum transferrin and ferritin in the $\mathrm{NaNO}_{2}$-induced rat followed by therapy with $\mathrm{S}$. androgynus chlorophyll and $\mathrm{Cu}$-chlorophyllin group compared with the control group.

3.3. Histopathological Evaluation. The histopathologic parameters for liver and proximal tubule epithelium of kidney were not significantly different among groups (Table 3), although there were increasing score of hepatocyte and proximal tubule epithelium damage in $\mathrm{NaNO}_{2}$-induced group. Histopathology of hepatocyte of rat liver in control group showed normal or no change with score 1, while the hepatocyte in $\mathrm{NaNO}_{2}$ induced group showed hydropic degeneration (Figure 1). The hepatocyte and proximal tubule kidney in group treated with dose $1 \mathrm{Cu}$-chlorophyllin showed the highest score of hepatocyte histopathologic view even not significantly different from the control. There was founded necrosis cell in proximal tubule kidney of rats treated by $\mathrm{Cu}$-chlorophyllin (Figure 2). The histology of kidney in the group cured with dose 1 of chlorophyll showed that the lesion cell was less than $50 \%$.

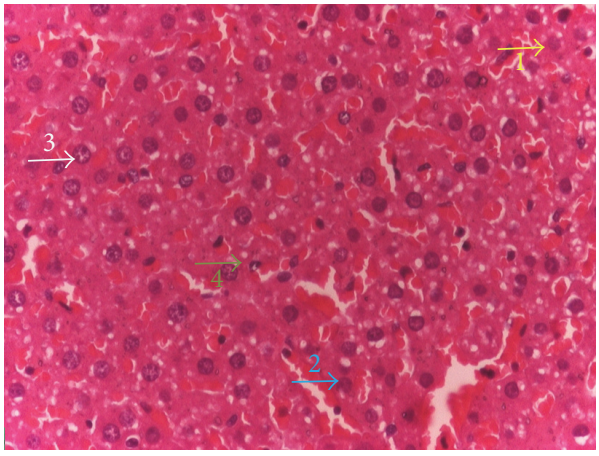

FIGURE 1: Representative microscopic tissue images of rat liver were given $50 \mathrm{mg} / \mathrm{kg} /$ day $\mathrm{NaNO}_{2}$ (H\&E). The histopathology scores of observation are 1 (yellow arrow), 2 (blue arrow), and 3 (white arrow) showing no changes, indicating mild/moderate and severe changes, respectively. Photographs were obtained by light microscopy at $400 \times$ magnification.

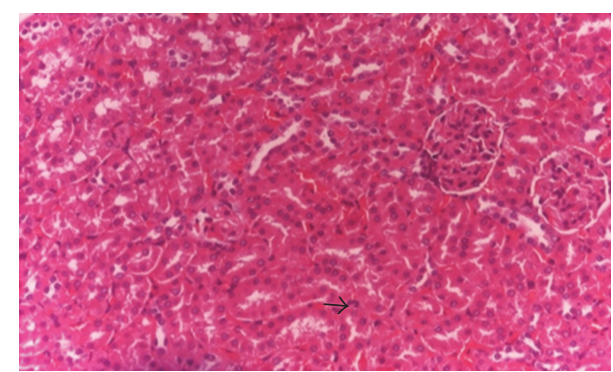

FIGURE 2: Representative microscopic tissue images of proximal tubule epithelium. Rats were given $50 \mathrm{mg} / \mathrm{kg} /$ day $\mathrm{NaNO}_{2}$ and $0,016 \mathrm{mg} / \mathrm{mL} \mathrm{Cu}$-chlorophyllin (H\&E). Necrosis cell (black arrow). Photographs were obtained by light microscopy at $400 \times$ magnification.

In the present study, intake of $\mathrm{NaNO}_{2}$ for 10 days resulted in haematological, biochemical, and histopathological changes in rats. This result was in accordance with Roth and Kate Smith [33] that rats given $\mathrm{NaNO}_{2}$ via drinking water at $1-3 \mathrm{~g} / \mathrm{L}$ during pregnancy and lactation showed decreasing of erythropoietic development, changing in some histopathological such as cytoplasmic vacuolization of centrilobular hepatocytes, and decreased hematopoiesis in bone marrow and spleen. Özen et al. [2] have detected hydropic cellular degeneration in liver and tubular degeneration in kidney 
TABLE 3: The degeneration score of hepatocyte and proximal tubule epithelium cell in each experimental group.

\begin{tabular}{|c|c|c|c|c|c|c|}
\hline Parameters & $\begin{array}{l}\text { Group I } \\
\text { control }\end{array}$ & $\begin{array}{l}\text { Group II } \\
\left(\mathrm{NaNO}_{2}\right)\end{array}$ & $\begin{array}{c}\text { Group III } \\
\left(\mathrm{NaNO}_{2}+\text { dose } 1 / 2\right. \\
\text { CSA })\end{array}$ & $\begin{array}{c}\text { Group IV } \\
\left(\mathrm{NaNO}_{2}+\text { dose } 1\right. \\
\text { CSA })\end{array}$ & $\begin{array}{c}\text { Group V } \\
\left(\mathrm{NaNO}_{2}+\text { dose } 1 / 2\right. \\
\mathrm{CuC})\end{array}$ & $\begin{array}{c}\text { Group VI } \\
\left(\mathrm{NaNO}_{2}+\text { dose } 1\right. \\
\mathrm{CuC})\end{array}$ \\
\hline Score of hepatocyte & $1.2 \pm 0.15$ & $2.08 \pm 0.23$ & $2.04 \pm 0.45$ & $1.96 \pm 0.45$ & $1.85 \pm 0.40$ & $2.48 \pm 0.39$ \\
\hline $\begin{array}{l}\text { Score of proximal } \\
\text { tubule epithelium } \\
\text { cell }\end{array}$ & $1.08 \pm 0.05$ & $1.32 \pm 0.10$ & $1.48 \pm 0.26$ & $1.20 \pm 0.09$ & $1.25 \pm 0.19$ & $2.08 \pm 0.12$ \\
\hline
\end{tabular}

Note: values are presented as mean \pm SE of five animals per group.

in $20 \mathrm{mg} / \mathrm{kg} /$ day $\mathrm{NaNO}_{2}$-induced mice for 8 months. The histopathological changes are mediated by oxidative stress produced by the action of the metabolic pathways generated against the toxic compounds.

Lanfer-Marquez et al. (2005) reported that $\mathrm{Cu}$-chlorophyllin tested by $\beta$-carotene bleaching method and the stable radical 2,2-diphenyl-1-picrylhydrazyl (DPPH) scavenging assay methods presented a higher antioxidant activity than that of natural chlorophylls, showing the importance of the nature of the chelated metal in the porphyrin ring. The mechanism of antioxidant activity displayed by the natural chlorophyll derivatives does not seem to be based on the ability to donate hydrogen but maybe, the protection of linoleic acid against oxidation, and/or preventing decomposition of hydroperoxides [11].

This is suggestive of hepatocytes protection from antioxidant activity from chlorophyll of $S$. androgynus against $\mathrm{NaNO}_{2}$-induced damages. The histopathologic parameters for liver showed $\mathrm{NaNO}_{2}$-induced toxicity and ameliorative potentials of chlorophyll of $S$. androgynus on $\mathrm{NaNO}_{2}-$ induced oxidative stress.

Chlorophyll is a molecule found in the green parts of plants. Chlorophyllin copper ( $\mathrm{Cu}$ (II)-chlorophyllin) is one of derivatives of chlorophyll that reported increased peripheral leukocyte count and improving symptoms of dizziness and fatigue in individuals with leukopenia [34]. Chlorophyll is converted to $\mathrm{Mg}$-free pheophytin derivatives during digestion and then transported to peripheral tissues. Chlorophylls degraded rapidly to pheophytins in response to the high acidity of the gastric phase [35]. In the past, chlorophyll has been used to treat gastrointestinal problems, anaemia, and cancer [36]. Fahey et al. [37] reported that chlorophyll can improve the function of essential detoxification pathways. Chlorophyllin was 410 -fold more potent as a phase 2 enzyme inducer than chlorophyll, since it has other detoxification properties because it is much more watersoluble than chlorophyll. Antioxidant activity of chlorophyll from plant leave also reported by Sakagami et al. [38] showed that Sasa senanensis Rehder leaf extract containing Fe(II)chlorophyllin demonstrated superoxide anion and hydroxyl radical-scavenging activity five times higher than a similar product containing $\mathrm{Cu}$ (II)-chlorophyllin and comparable to a product containing $\mathrm{Cu}(\mathrm{II})$-chlorophyllin, ginseng, and pine leaf extracts. Therefore, the data obtained from this study further proved the usefulness of chlorophyll of S. androgynus as a food supplement that may be recommended to cure humans and animals from $\mathrm{NaNO}_{2}$ toxicity.

\section{Conclusion}

The present study has demonstrated the curative effect of chlorophyll solution from $S$. androgynus leaves on haematological, serum biochemical, and histological parameters, altered by sodium nitrate exposure in female Wistar rats. This amelioration may be partly due to the antioxidant activity of chlorophyll from $S$. androgynus leaves that possess remarkable potential to cure the oxidative stress caused by sodium nitrate. Further assessment of molecular evaluations of biological activities of chlorophyll from S. androgynus needs to be studied.

\section{Competing Interests}

No potential conflict of interests was reported by the authors.

\section{Acknowledgments}

This study was supported by Hibah Penelitian Kerjasama Antar Perguruan Tinggi (PEKERTI) from Ministry of Research, Technology and Higher Education, Indonesia, with Contract no. 172/B.I/SA-LPPM/IV/2015 at April 20, 2015.

\section{References}

[1] A. J. De Roos, M. H. Ward, C. F. Lynch, and K. P. Cantor, "Nitrate in public water supplies and the risk of colon and rectum cancers," Epidemiology, vol. 14, no. 6, pp. 640-649, 2003.

[2] H. Özen, U. Kamber, M. Karaman et al., "Histopathologic, biochemical and genotoxic investigations on chronic sodium nitrite toxicity in mice," Experimental and Toxicologic Pathology, vol. 66, no. 8, pp. 367-375, 2014.

[3] A. Alyoussef and M. M. H. Al-Gayyar, "Thymoquinone ameliorated elevated inflammatory cytokines in testicular tissue and sex hormones imbalance induced by oral chronic toxicity with sodium nitrite," Cytokine, vol. 83, pp. 64-74, 2016.

[4] S. R. Naik, V. W. Pilgaonkar, and V. S. Panda, "Evaluation of antioxidant activity of Ginkgo biloba phytosomes in rat brain," Phytotherapy Research, vol. 20, no. 11, pp. 1013-1016, 2006.

[5] D. Y. Atanasova and N. E. Lazarov, "Morphological changes in the rat carotid body following acute sodium nitrite treatment," Respiratory Physiology and Neurobiology, vol. 221, pp. 11-18, 2016.

[6] M. G. Ferruzzi and J. Blakeslee, "Digestion, absorption, and cancer preventative activity of dietary chlorophyll derivatives," Nutrition Research, vol. 27, no. 1, pp. 1-12, 2007. 
[7] P. Vivek, S. Prabhakaran, and S. R. Shankar, "Assessment of nutritional value in selected edible greens based on the chlorophyll content in leaves," Research in Plant Biology, vol. 3, no. 5, 2013.

[8] J. R. Shelton and D. N. Vincent, "Retarded autoxidation and the chain-stopping action of inhibitors," Journal of the American Chemical Society, vol. 85, no. 16, pp. 2433-2439, 1963.

[9] A. L. İnanç, “Chlorophyll: structural properties, health benefits and its occurrence in virgin olive oils," Akademik Gida, vol. 9, pp. 26-32, 2011.

[10] R. Pangestuti and S.-K. Kim, "Biological activities and health benefit effects of natural pigments derived from marine algae," Journal of Functional Foods, vol. 3, no. 4, pp. 255-266, 2011.

[11] U. M. Lanfer-Marquez, R. M. C. Barros, and P. Sinnecker, "Antioxidant activity of chlorophylls and their derivatives," Food Research International, vol. 38, no. 8-9, pp. 885-891, 2005.

[12] Y. Endo, R. Usuki, and T. Kaneda, "Antioxidant effects of chlorophyll and pheophytin on the autoxidation of oils in the dark. II. The mechanism of antioxidative action of chlorophyll," Journal of the American Oil Chemists' Society, vol. 62, no. 9, pp. 1387-1390, 1985.

[13] S. Singh, D. R. Singh, K. M. Salim, A. Srivastava, L. B. Singh, and R. C. Srivastava, "Estimation of proximate composition, micronutrients and phytochemical compounds in traditional vegetables from Andaman and Nicobar Islands," International Journal of Food Sciences and Nutrition, vol. 62, no. 7, pp. 765773, 2011.

[14] N. Andarwulan, R. Batari, D. A. Sandrasari, B. Bolling, and H. Wijaya, "Flavonoid content and antioxidant activity of vegetables from Indonesia," Food Chemistry, vol. 121, no. 4, pp. 1231-1235, 2010.

[15] P. Ramesh Kumar and P. George, "Antidiabetic effect of Sauropus androgynus L. leaves in alloxan induced diabetic mice," Journal of Pure and Applied Microbiology, vol. 9, no. 3, pp. 25652570, 2015.

[16] T. Yuniarti, Ensiklopedia Tanaman Obat Tradisional, MedPress, Yogyakarta, Indonesia, 2008.

[17] N. K. Warditiani, Milawati, and N. M. P. Susanti, "Anti dyslipidemic activity of Katuk leaves saponins fraction (Sauropus androgynus (L) Merr) in rats induced with fat-rich diet," International Journal of Pharmacy and Pharmaceutical Sciences, vol. 8, pp. 418-420, 2016.

[18] A. P. A. Samad, U. Santoso, M.-C. Lee, and F.-H. Nan, "Effects of dietary katuk (Sauropus androgynus L. Merr.) on growth, non-specific immune and diseases resistance against Vibrio alginolyticus infection in grouper Epinephelus coioides," Fish and Shellfish Immunology, vol. 36, no. 2, pp. 582-589, 2014.

[19] N. Anna, A. M. Ednisari, G. D. Urfani, I. Laila, and H. R. Saintika, "Anti-anemia effect of chlorophyll from katuk (Sauropus androgynus) leaves on female mice induced sodium nitrite," Pharmacognosy Journal, vol. 8, no. 4, pp. 375-379, 2016.

[20] I. Ivanov, Y. Gluhcheva, E. Petrova, and N. Antonova, "Hemorheological changes and hematometric erythrocyte characteristics in rats after sodium nitrite intoxication," Korea Australia Rheology Journal, vol. 26, no. 2, pp. 225-228, 2014.

[21] P. V. Tan, C. Mezui, G. Enow-Orock, N. Njikam, T. Dimo, and P. Bitolog, "Teratogenic effects, acute and sub chronic toxicity of the leaf aqueous extract of Ocimum suave Wild (Lamiaceae) in rats," Journal of Ethnopharmacology, vol. 115, no. 2, pp. 232-237, 2008.
[22] N. Abuharfeil, E. Sarsour, and M. Hassuneh, "The effect of sodium nitrite on some parameters of the immune system," Food and Chemical Toxicology, vol. 39, no. 2, pp. 119-124, 2001.

[23] J. D. Hernández Hernández, O. R. Villaseñor, J. Del Rio Alvarado et al., "Morphological changes of red blood cells in peripheral blood smear of patients with pregnancy-related hypertensive disorders," Archives of Medical Research, vol. 46, no. 6, pp. 479-483, 2015.

[24] Y. Gluhchevaa, I. Ivanovb, E. Petrovaa, E. Pavlovaa, and I. Vladova, "Sodium nitrite-induced hematological and hemorheological changes in rats," Series on Biomechanic, vol. 27, pp. 5358, 2012.

[25] P. W. Buehler, O. I. Butt, and F. D’Agnillo, "Sodium nitrite induces acute central nervous system toxicity in guinea pigs exposed to systemic cell-free hemoglobin," Biochemical and Biophysical Research Communications, vol. 409, no. 3, pp. 412417, 2011.

[26] J. H. Baek, X. Zhang, M. C. Williams, W. Hicks, P. W. Buehler, and F. D'Agnillo, "Sodium nitrite potentiates renal oxidative stress and injury in hemoglobin exposed guinea pigs," Toxicology, vol. 333, pp. 89-99, 2015.

[27] J. Balla, K. A. Nath, G. Balla, M. B. Juckett, H. S. Jacob, and G. M. Vercellotti, "Endothelial cell heme oxygenase and ferritin induction in rat lung by hemoglobin in vivo," American Journal of Physiology_Lung Cellular and Molecular Physiology, vol. 268, no. 2, pp. L321-L327, 1995.

[28] K.-I. Yamada, I. Yamamiya, and H. Utsumi, "In vivo detection of free radicals induced by diethylnitrosamine in rat liver tissue," Free Radical Biology and Medicine, vol. 40, no. 11, pp. 20402046, 2006.

[29] M. Ahotupa, V. Bussacchini-Griot, J.-C. Béréziat, A.-M. Camus, and H. Bartsch, "Rapid oxidative stress induced by Nnitrosamines," Biochemical and Biophysical Research Communications, vol. 146, no. 3, pp. 1047-1054, 1987.

[30] C. K. Chow and C. B. Hong, "Dietary vitamin E and selenium and toxicity of nitrite and nitrate," Toxicology, vol. 180, no. 2, pp. 195-207, 2002.

[31] H. A. Hassan and M. I. Yousef, "Ameliorating effect of chicory (Cichorium intybus L.)-supplemented diet against nitrosamine precursors-induced liver injury and oxidative stress in male rats," Food and Chemical Toxicology, vol. 48, no. 8-9, pp. 21632169, 2010.

[32] N. M. El-Sheikh and F. A. Khalil, "L-Arginine and l-glutamine as immunonutrients and modulating agents for oxidative stress and toxicity induced by sodium nitrite in rats," Food and Chemical Toxicology, vol. 49, no. 4, pp. 758-762, 2011.

[33] A. C. Roth and M. Kate Smith, "Nitrite-induced iron deficiency in the neonatal rat," Toxicology and Applied Pharmacology, vol. 96, no. 1, pp. 43-51, 1988.

[34] F. Gao and X.-F. Hu, "Analysis of the therapeutic effect of sodium copper chlorophyllin tablet in treating 60 cases of leukopenia," Chinese Journal of Integrative Medicine, vol. 11, no. 4, pp. 279-282, 2005.

[35] M. G. Ferruzzi, M. L. Failla, and S. J. Schwartz, "Assessment of degradation and intestinal cell uptake of carotenoids and chlorophyll derivatives from spinach puree using an in vitro digestion and Caco-2 human cell model," Journal of Agricultural and Food Chemistry, vol. 49, no. 4, pp. 2082-2089, 2001.

[36] B. Gruskin, "Chlorophyll-Its therapeutic place in acute and suppurative disease. Preliminary report of clinical use and rationale," The American Journal of Surgery, vol. 49, no. 1, pp. 49-55, 1940. 
[37] J. W. Fahey, K. K. Stephenson, A. T. Dinkova-Kostova, P. A. Egner, T. W. Kensler, and P. Talalay, "Chlorophyll, chlorophyllin and related tetrapyrroles are significant inducers of mammalian phase 2 cytoprotective genes," Carcinogenesis, vol. 26, no. 7, pp. 1247-1255, 2005.

[38] H. Sakagami, S. Iwamoto, T. Matsuta et al., "Comparative study of biological activity of three commercial products of Sasa senanensis Rehder leaf extract," In Vivo, vol. 26, no. 2, pp. 259264, 2012. 

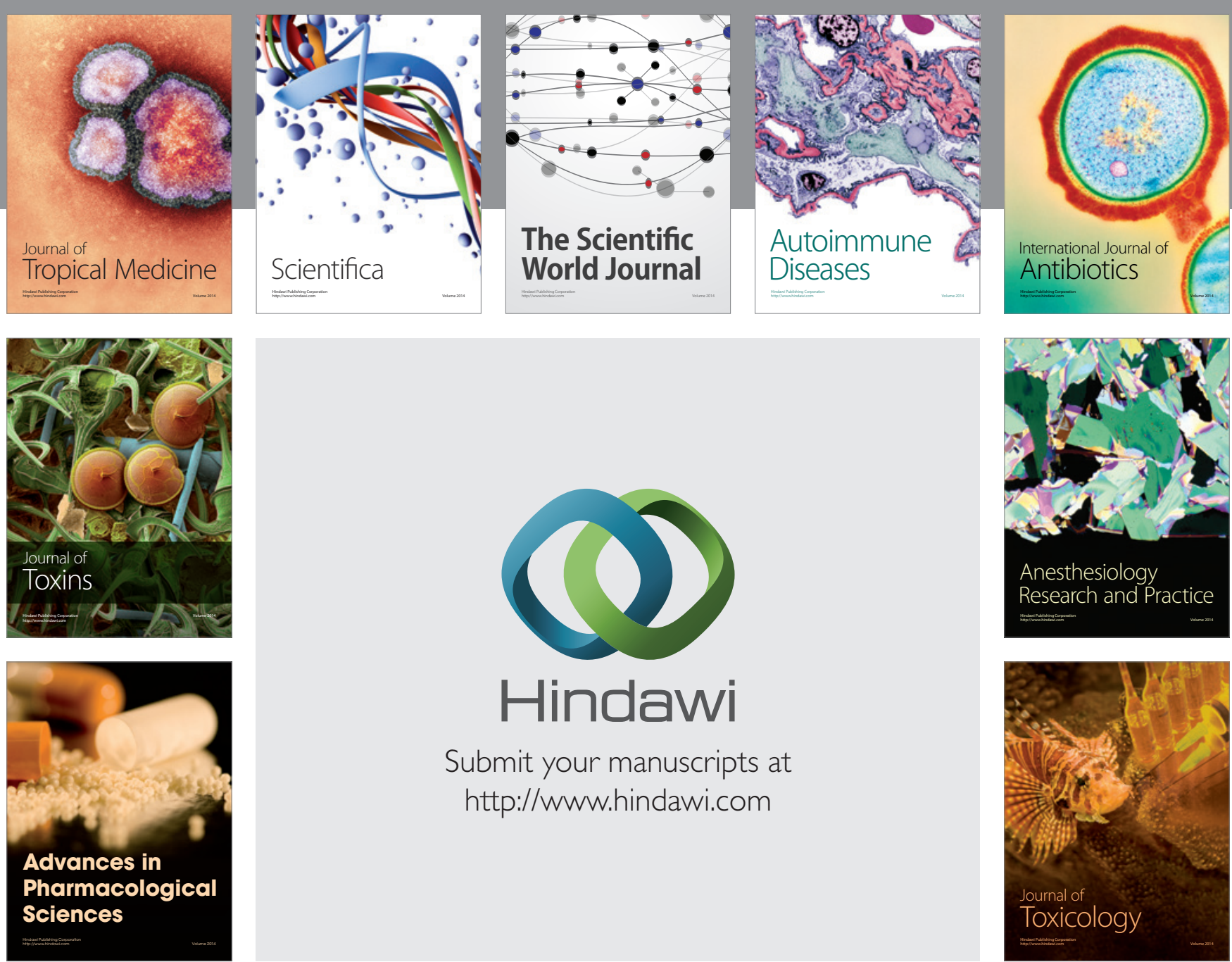

\section{Hindawi}

Submit your manuscripts at

http://www.hindawi.com
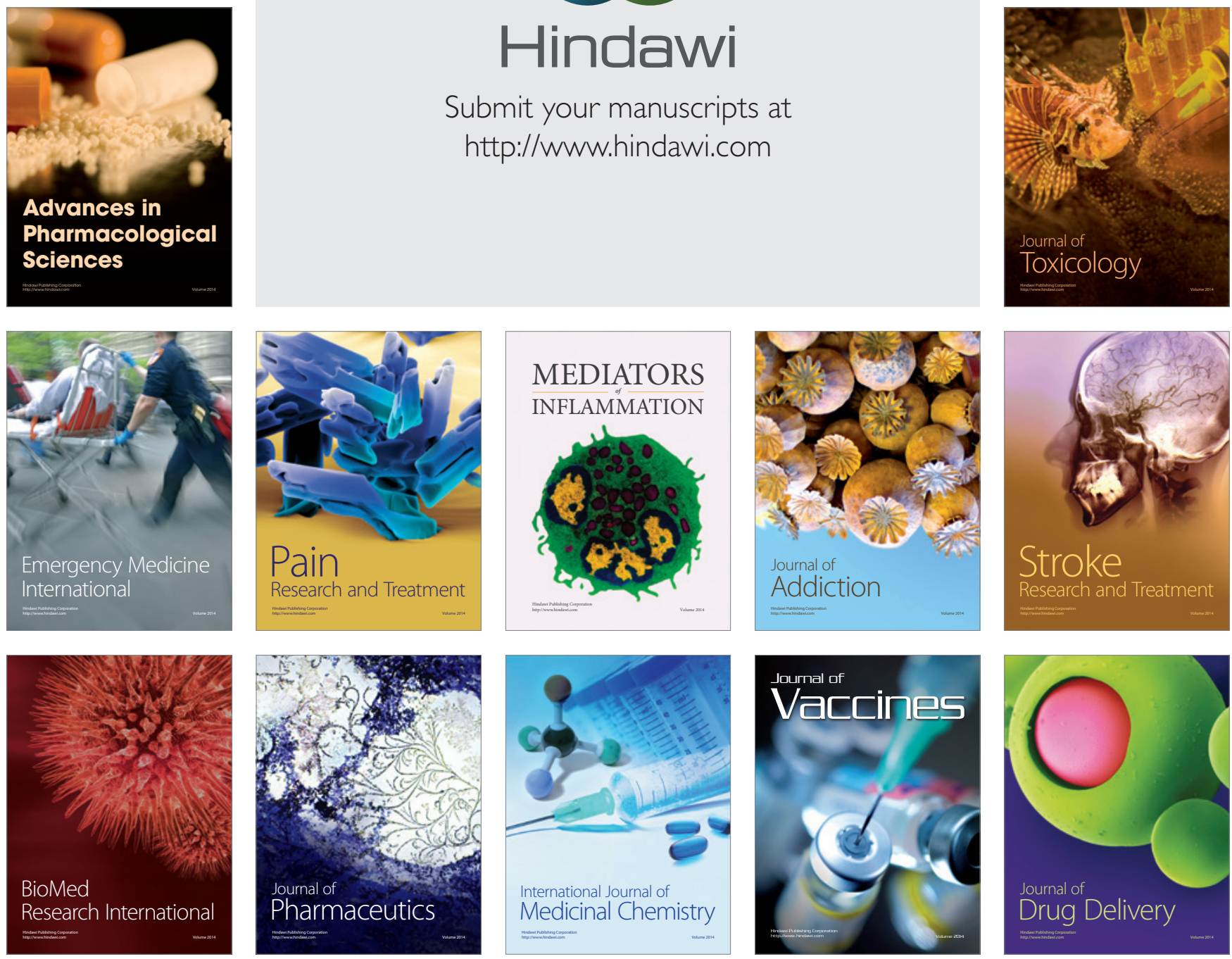